\title{
Effect of drying temperature on polyphenolic content and antioxidant activity of apricots
}

\author{
Monica A. Madrau • Amalia Piscopo • \\ Anna M. Sanguinetti · Alessandra Del Caro • \\ Marco Poiana · Flora V. Romeo · Antonio Piga
}

Received: 12 May 2008/Revised: 18 August 2008/Accepted: 3 September 2008/Published online: 24 September 2008

(C) The Author(s) 2008. This article is published with open access at Springerlink.com

\begin{abstract}
This study was carried out in order to check for the influence of drying parameters on the phenolic compounds and antioxidant activity on two apricot cultivars (Pelese and Cafona) using two sets of air drying temperatures: (1) air temperature at $55^{\circ} \mathrm{C}$; (2) air temperature at $75{ }^{\circ} \mathrm{C}$. Whole fresh and dried fruits were assessed for: phenolics, ascorbic acid, antioxidant activity and redox potential (all parameters were calculated on a dry matter basis). Analysis of data shows that the decrease in chlorogenic and neochlorogenic acid in Cafona cultivar is higher at the lower drying temperature. Catechin showed the same behaviour of hydroxycinnamic acids in both cultivars, while the decrease in the other compounds was significantly more marked in the sample dried at $75^{\circ} \mathrm{C}$. The antioxidant activity increased significantly in Cafona fruits and this increase was confirmed by a diminution of the redox potential.
\end{abstract}

Keywords Catechins - Flavonols - Hot air drying · Hydroxicinnamic acids $\cdot$ Redox potential

\section{Introduction}

According to Kalra [1], "Functional foods or nutraceuticals aid in the prevention and/or treatment of diseases or

M. A. Madrau - A. M. Sanguinetti - A. Del Caro · A. Piga ( $₫)$ Dipartimento di Scienze Ambientali Agrarie e Biotecnologie Agro-Alimentari, Università degli Studi di Sassari,

Viale Italia 39, 07100 Sassari, Italy

e-mail: pigaa@uniss.it

\section{A. Piscopo $\cdot$ M. Poiana $\cdot$ F. V. Romeo}

Dipartimento di Biotecnologie per il Monitoraggio

Agroalimentare ed Ambientale, Università degli Studi

Mediterranea, Piazza San Francesco di Sales 4, 89131 Gallina,

Reggio Calabria, Italy disorders other than anaemia". These beneficial effects are associated with the constitutive presence in the products of biologically active components, like carotenoids, phenolics, some vitamins and fibres. Apricot fruits, in this context, may be considered as a rich source of the above cited phytochemicals, mainly polyphenols [2-10] and carotenoids $[4,10-12]$. Phenolics, in particular, are thought to act as antioxidant, anti-carcinogenic, anti-microbial, anti-allergic, anti-mutagenic and anti-inflammatory, as well as reduce cardiovascular diseases [13]. Carotenoids, on the other hand, are converted into vitamin A in the body. Changes of these phytochemicals in apricots have been studied during ripening $[3,10]$, in relation to cultivar $[8,10,12,14]$ or after puree preparation [8]. Literature reports contrasting results about the importance of fresh apricot fruits in terms of antioxidant activity. Guo et al. [15], in fact, ranked the antioxidant activity of apricot fruit (determined by FRAP) between the16th and the 24th among 28 fruits, depending on the part considered (pulp, peel or seed), while Ishiwata et al. [16] ranked fresh apricots the first among 25 fruits. The antioxidant activity of apricots was found to be quite all dependent on polyphenols [15].

However, we have to consider that apricots are processed on a basis of $40-45 \%$ of total world production [17]. Drying is one of the technologies commonly used [18]. Sun drying of sulphured fruit is the conventional method, requiring low capital, simple equipment and low energy input. In particular, this method is able to produce apricots of a rich orange colour, translucent appearance and very good gumminess [19]. However, there is an increasing request of sulphur free dried apricots, due to the allergic reactions that high concentrations of sulphites may cause in sensitive individuals. Nonetheless, mechanical air dehydration has gained importance because it has many advantages over sun drying [20, 21]. High drying temperatures used in mechanical air 
dehydration may lead to phenolics depletion, while carotenoids are mainly degraded by the exposure to large amounts of oxygen. The literature does not clearly explain the effect of drying on the phenolic content and antioxidant activity of apricot fruit. Güclü et al. [22] reported a new spectrophotometric method (CUPRAC) for the assay of total antioxidant activity of fresh and dried (sun and sulphited) apricots. This paper revealed an increase in antioxidant activity (even if the authors refer the data to gram of solid matter, it is not well clear if they meant dry matter), but did not consider the fate of single polyphenols. In the work of Ishiwata et al. [16] it is reported that dried fruits had lower antioxidant values compared to fresh one; however, it is not well clear if the dried fruits have been obtained by the same fresh fruits, whose data are reported. In another fruit, the plum, has been demonstrated that, although the high processing temperatures used to dry the fruits reduced significantly both the polyphenol and ascorbic acid content, the antioxidant activity of the dried prunes was significantly increased [23].

For this reason, this paper is aimed to evaluate the effects of hot air drying at two different temperatures on the main phenolic compounds, on antioxidant capacity and redox potential of the only water-soluble fraction of apricots, since the lipophilic contribute to the antioxidant activity has been demonstrated to be very low [14]. Optimisation of processing procedures could undoubtedly lead to improvements in the functionality and health promoting capacity of these fruits, avoiding in turn all the hygienic concerns of sun dried apricots.

\section{Materials and methods}

The experiments were conducted on two varieties of apricots: Pelese and Cafona. We considered these two varieties for their phenolic content, very low in the Pelese and very high in the Cafona.

\section{Plant material}

The fruits were purchased locally at an optimum stage of ripening and those showing defects were discarded. Fruits were size-graded, so that size difference would not affect drying times. Fruits were cut in half along the suture line with a knife and the stone carefully removed by hand. At the end of this procedure, the fruits were immediately checked to eliminate anyone that had been damaged and then, dried.

\section{Chemicals}

HPLC grade methanol, RPE ACS-ISO methanol and hydrochloric acid were purchased from Carlo Erba
Reagenti (Rodano, Milano, Italy); tert-butylhydroquinone (t-BHQ), 2,2 diphenyl-1-picrylhydrazyl (DPPH), 2,6dichloroindophenol, chlorogenic acid, catechin and epicatechin were obtained by Sigma-Aldrich Chemical Co. (St Louis, MO, USA) and rutin and quercetin 3-O-glucoside from Extrasynthese (B.P. 62-69730, Genay, France). Neochlorogenic acid was kindly provided by Dr. Murray Isman (Department of Plant Sciences, University of British Columbia, Vancouver).

\section{Dehydration}

Fruits were dried in a laboratory pilot dryer, a tangential air-flow cabinet (a modified model of "Scirocco", Società Italiana Essiccatoi, Milan, Italy), equipped with automatic temperature and air moisture control devices. Air flows tangentially to fruits, while an air recycling system allows mixing exhaust with fresh air and then reheating and redirecting to the product, in order to achieve the desired air moisture. The particular construction of the drier allows a continuous airflow on the fruits, avoiding turbulence, thus it is particularly suited to calculate drying kinetics. The fruits were placed on $56 \mathrm{~cm}$ diameter steel food trays (with a $13-15 \mathrm{~kg} / \mathrm{m}^{2}$ load, depending on variety) and loaded into the drier, where they were dried until reaching a predetermined dry matter (DM) value of $80 \%$ (based on weight loss calculation). The process was carried out at two different temperature settings: in the first case the air temperature was set at $75^{\circ} \mathrm{C}$, while in the second case the air temperature was set at $55^{\circ} \mathrm{C}$ throughout the process. In both cases the relative humidity of the air was as high as possible in the first stage $(\approx 40 \%)$, while the air volume was $1,840 \mathrm{~m}^{3} / \mathrm{h}$. The air was constantly recycled throughout the process and regulated to maintain the pre-set humidity values. The lower temperature can be considered a "mild" drying temperature, and could be expected to give low thermal damage to fruits, the higher was chosen to increase non enzymatic browning and see the effects on polyphenolics and antioxidant activity and then compare with the effects of the lower temperature. Before analysis the dried fruits were packed in co-extruded plastic bags (95 $\mu \mathrm{m}$ thick polyethylene/polypropylene) and kept in a freezer at $-18{ }^{\circ} \mathrm{C}$.

Analysis and quantitative determinations

Fresh and dried fruits were evaluated differently. Thirty fresh apricots were stoned and homogenised using a Waring blender. The following analyses were carried out in triplicate on the puree: water content $(\%)$, determined in a vacuum oven for $22 \mathrm{~h}$ at $70{ }^{\circ} \mathrm{C}$ [24]; water activity of fruit puree, assessed by an electronic hygrometer (Aw-Win, Rotronic, Huntington, NY, USA) equipped with a Karl-Fast probe 
calibrated in the range $0.1-0.95$ with solutions of $\mathrm{LiCl}$ of known activity; $\mathrm{pH}$, determined on homogenised fruit flesh by a digital $\mathrm{pH}$ meter; acidity, expressed as $\mathrm{g}$ of citric acid per $100 \mathrm{~g}$ of dry matter (DM) by titration with $0.1 \mathrm{~N} \mathrm{NaOH}$ to end point ( $\mathrm{pH} 8.3$ ); ascorbic acid $\left(\mathrm{mg} \mathrm{g} \mathrm{DM}^{-1}\right)$ by titration with 2,6-dichloroindophenol [24]. The antioxidant capacity was evaluated using the free radical 2,2 diphenyl-1-picrylhydrazyl (DPPH) [25]: $25 \mathrm{~mL}$ of distilled $\mathrm{H}_{2} \mathrm{O}$ were added to $5 \mathrm{~g}$ of homogenised puree $(3 \mathrm{~g}$ were used for the dried samples), placed in the vortex for $1 \mathrm{~min}$ and centrifuged at 4,000g at room temperature for $15 \mathrm{~min}$ [23]. The supernatant was filtered through a Whatman n. 4 filter and then, before the spectrophotometric reading (HP 8453 spectrophotometer, Palo Alto, CA, USA), through a $0.45 \mu \mathrm{m}$ filter. After that $50 \mu \mathrm{L}$ of the solution were made to react for $2 \mathrm{~h} 30 \mathrm{~m}$ in a cuvette containing $3 \mathrm{~mL}$ of a $6 \times 10^{-5} \mathrm{M}$ methanol solution of DPPH, at $515 \mathrm{~nm}$ wavelength and a temperature of $25{ }^{\circ} \mathrm{C}$, in order to obtain a decrease in absorbance by the radical DPPH (the decolouration curve of the radical follows very slow kinetics). A graph of absorbance versus time showed that its decrease followed a fourth order kinetic $\left(r^{2} \geq 0.99\right)$. Antioxidant capacity was expressed with the following $\mathrm{OD}^{-3} \mathrm{~min}^{-1} \mathrm{~g} \mathrm{DM}^{-1}$, in the equation:

$\frac{1}{A^{3}}-\frac{1}{A_{0}^{3}}=-3 k t$

where $A_{0}$ is the initial optical density and $A$ is the optical density at rising time $t$, OD is optical density.

The redox potential was assessed potentiometrically with a platinum indicating electrode and a $\mathrm{Ag} / \mathrm{AgCl}, \mathrm{Cl}^{-}$sat reference electrode connected to a voltmeter. Calibration was performed against a redox standard solution $\left(E=220 \pm 5 \mathrm{mV}\right.$ at $\left.25^{\circ} \mathrm{C}\right)$. Measurement was performed as reported by Manzocco et al. [26].

The phenols were extracted using the method proposed by Dragovic-Uzelac et al. [10], with slight modifications, and analysed in HPLC according to the method described by Donovan et al. [27]. In detail, a sample of $50 \mathrm{~g}$ was homogenised, mixed with a $50 \mathrm{~mL}$ methanol/ $\mathrm{HCl}(100: 1 \mathrm{v} / \mathrm{v})$ solution containing $1 \mathrm{mg}$ of tert-butylhydroquinone and left to macerate at room temperature and under $\mathrm{N}_{2}$ for $20 \mathrm{~h}$. The resulting slurry was centrifuged at $2,800 \mathrm{~g}$ for $15 \mathrm{~min}$ at $15^{\circ} \mathrm{C}$, filtered with Whatman 4 filter paper and then extracted three times with $40 \mathrm{~mL}$ of ethyl acetate. The three collected phases were dried with anhydrous $\mathrm{Na}_{2} \mathrm{SO}_{4}$ and filtered again with Whatman 4 filter paper. The resulting sample was rotary evaporated to dryness at $35^{\circ} \mathrm{C}$, dissolved in $3 \mathrm{~mL}$ of a $\mathrm{H}_{2} \mathrm{O} /$ $\mathrm{MeOH}(50: 50 \mathrm{v} / \mathrm{v})$ solution and filtered with a $0.20 \mu \mathrm{m}$ PTFE syringe filter. The sample was then stored at $-20{ }^{\circ} \mathrm{C}$ until analysis. HPLC-DAD analysis was performed by a Hewlett Packard liquid chromatograph (Palo Alto, CA, USA), Series 1090, coupled with an HP 1050 diode array detector. The column was a Gemini $\mathrm{C}_{18}, 250 \times 4.6 \mathrm{~mm}, 5 \mu \mathrm{m}$ (Phenomenex); $10 \mu \mathrm{L}$ loop; $0.5 \mathrm{~mL} / \mathrm{min}$ flow; mobile phase: $\mathrm{A}=50 \mathrm{mM} \mathrm{NH} \mathrm{H}_{2} \mathrm{PO}_{4}$ solution brought to $2.6 \mathrm{pH}$ with $\mathrm{H}_{3} \mathrm{PO}_{4}, \mathrm{~B}=80 \% \mathrm{CH}_{3} \mathrm{CN}$ and $20 \%$ phase $\mathrm{A}, \mathrm{C}=200 \mathrm{mM}$ $\mathrm{H}_{3} \mathrm{PO}_{4}$. The following gradient was used: $100 \% \mathrm{~A}$ at $5 \mathrm{~min}$, $92 \% \mathrm{~A}$ and $8 \% \mathrm{~B}$ at $8 \mathrm{~min}, 14 \% \mathrm{~B}$ and $86 \% \mathrm{C}$ at $20 \mathrm{~min}$, $16.5 \% \mathrm{~B}$ and $83.5 \% \mathrm{C}$ at $25 \mathrm{~min}, 21.5 \% \mathrm{~B}$ and $78.5 \% \mathrm{C}$ at $35 \mathrm{~min}, 50 \% \mathrm{~B}$ and $50 \% \mathrm{C}$ at $70 \mathrm{~min} ; 100 \% \mathrm{~A}$ at $75 \mathrm{~min}$, $100 \% \mathrm{~A}$ at $80 \mathrm{~min}$. The phenols were monitored at 4 different wavelengths: $280 \mathrm{~nm}$ for catechins, $316 \mathrm{~nm}$ for hydroxycinnamic acids, $355 \mathrm{~nm}$ for flavonols and $510 \mathrm{~nm}$ for anthocyanins. The methanolic extracts were separated by HPLC and retention times and UV spectra recorded. The pure standards of the compounds were available to identify the major peaks. A very complete study has been recently published on the determination of phenolics in apricots by HPLC [10]; the authors identified some phenolic compounds only by polarity and spectral data from literature. We do not feel confident with this identification procedure, thus we do not make assignment of unknown peaks on the basis of the method proposed by these authors. The peak assignment, in fact, was done only when there was a full correspondence of retention time and spectra of the eluting compound and the injected pure standard. The identified compounds were then quantified by calibration with the following standards: catechin and epicatechin, neochlorogenic acid, chlorogenic acid, rutin and quercetin 3-O-glucoside. We found two other compounds in the samples which we did not have standards for. These were quantified one as epicatechin equivalent and the other as rutin equivalent, since their spectra, were very similar to those generated after the injection of epicatechin and rutin standards. All values were expressed as $\mathrm{mg} \mathrm{kg}^{-1} \mathrm{DM}^{-1}$. Both the fresh and the dried samples were analysed.

Statistical analysis

The experiment was repeated twice with the same results, thus data of one of the experiment will be considered. All data were submitted to one-way analysis of variance (ANOVA) using MSTAT-C software, considering sampling time (fresh and dried) as "group variable". Means, when required, were separated according to Duncan's multiple range test, significance level $P \leq 0.01$.

\section{Result and discussion}

\section{Characterisation of fresh fruits}

Data on the physicochemical parameters of the fresh apricots are shown in Table 1 . It can be seen that the DM values indicate that the fruit is suitable for drying, while the ratio DM/acids is low, if compared to Turkish varieties, 
Table 1 Phisicochemical parameters in fruits (fresh and dried) of two apricot cultivars

\begin{tabular}{|c|c|c|c|c|c|c|c|}
\hline Cultivar & Sample & $\begin{array}{l}\text { Dry matter } \\
(\%)\end{array}$ & Aw & $\mathrm{pH}$ & $\begin{array}{l}\text { Acidity } \\
\text { (\% citric acid) }\end{array}$ & $\begin{array}{l}\text { Acidity (g citric } \\
\left.\text { acid } 100 \mathrm{~g}^{-1} \mathrm{DM}^{-1}\right)\end{array}$ & $\begin{array}{l}\text { Ascorbic acid } \\
\left(\mathrm{mg} 100 \mathrm{~g}^{-1} \mathrm{DM}^{-1}\right)\end{array}$ \\
\hline \multirow[t]{3}{*}{ Pelese } & Fresh & $16.09 \mathrm{~b}$ & $0.961 \mathrm{a}$ & $3.77 \mathrm{a}$ & $1.19 \mathrm{c}$ & $7.39 \mathrm{a}$ & $22.01 \mathrm{a}$ \\
\hline & Dried $55^{\circ} \mathrm{C}$ & $79.84 \mathrm{a}$ & $0.719 \mathrm{~b}$ & $3.89 \mathrm{a}$ & $4.67 b$ & $5.85 b$ & $2.32 \mathrm{~b}$ \\
\hline & Dried $75^{\circ} \mathrm{C}$ & $80.17 \mathrm{a}$ & $0.712 b$ & $3.91 \mathrm{a}$ & $4.82 \mathrm{a}$ & $6.01 \mathrm{~b}$ & $2.48 \mathrm{~b}$ \\
\hline \multirow[t]{3}{*}{ Cafona } & Fresh & $15.71 \mathrm{~b}$ & $0.998 \mathrm{a}$ & $3.34 \mathrm{a}$ & $1.53 \mathrm{c}$ & $9.72 \mathrm{a}$ & $28.56 a$ \\
\hline & Dried $55^{\circ} \mathrm{C}$ & $79.86 a$ & $0.612 b$ & $3.45 \mathrm{a}$ & $6.17 \mathrm{~b}$ & $7.68 \mathrm{c}$ & $3.25 \mathrm{~b}$ \\
\hline & Dried $75^{\circ} \mathrm{C}$ & $80.85 a$ & $0.600 \mathrm{~b}$ & $2.99 \mathrm{~b}$ & $7.33 \mathrm{a}$ & $9.07 b$ & $3.57 \mathrm{~b}$ \\
\hline
\end{tabular}

Data followed by different letters within each column and cultivar are significantly different according to Duncan's Multiple Range Test at $P<0.01$

like Hacilaliloglu [17]. However, it is to remember that the aim of this work was to check the fate of polyphenols and antioxidant activity after hot air drying, thus we do not care about sensory properties of the dried product, when choosing the cultivars. The two apricot varieties examined showed fairly similar $\mathrm{pH}$ and acidity values, which are in the range reported in literature [28].

\section{Dehydration kinetics}

Under our experimental conditions the time necessary to reach the estimated value of DM varied, as was expected, according to the set of values used. Processing time was 21 and $25 \mathrm{~h}$ for Cafona and Pelese, respectively, in high temperature conditions $\left(75^{\circ} \mathrm{C}\right)$, while it ranged from 31 to 39 when the dehydration temperature was lower. The difference is due to the fact that the Pelese apricots had a much higher mean weight than the Cafona fruits (data not shown).

Physicochemical changes in the dried fruits

The physicochemical changes observed after drying are shown in Table 1. An increase in pulp $\mathrm{pH}$ and a decrease in titratable acidity (as DM) were generally observed, with the exception of the $\mathrm{pH}$ value of the $75^{\circ} \mathrm{C}$ dried Cafona fruits. Water activity values were quite always above the threshold for microbial growth, but since sugar content is high, an increase in microbes is unlikely. Moreover, apricots are rehydrated with water added with chemicals to prevent microbial growth, before packing and selling. A marked decrease in ascorbic acid content was found after the dehydration process, with no significant differences between drying temperatures. Loss of vitamin $\mathrm{C}$ after heat treatment has been widely reported [29].

Phenolic composition of fresh fruits and changes after drying

The Table 2 shows the percentages of the single compounds or classes of phenols found in fresh apricots. The two
Table 2 Absolute and percent amounts of phenolic compounds in two cultivars of fresh apricot fruits

\begin{tabular}{|c|c|c|c|c|}
\hline \multirow[t]{3}{*}{ Compound } & \multicolumn{4}{|l|}{ Cultivar } \\
\hline & \multicolumn{2}{|l|}{ Pelese } & \multicolumn{2}{|l|}{ Cafona } \\
\hline & Absolute $^{\mathrm{a}}$ & $\%$ & Absolute & $\%$ \\
\hline Neochlorogenic acid & 29.94 & 16.44 & 267.39 & 19.97 \\
\hline Chlorogenic acid & 24.16 & 13.26 & 505.19 & 37.71 \\
\hline Catechin & 13.39 & 7.35 & 232.14 & 17.33 \\
\hline Epicatechin & 11.37 & 6.24 & 145.06 & 10.83 \\
\hline Epicatechin equivalent & 11.84 & 6.50 & - & - \\
\hline Rutin & 67.59 & 37.11 & 167.20 & 12.48 \\
\hline Rutin equivalent & 17.32 & 9.51 & - & - \\
\hline Quercetin 3-glucoside & 6.52 & 3.58 & 22.57 & 1.68 \\
\hline & \multicolumn{4}{|c|}{ Percent values per class } \\
\hline \% Hydroxycinnamic acids & & 29.70 & & 57.68 \\
\hline$\%$ Flavanols & & 20.10 & & 28.16 \\
\hline$\%$ Flavonols & & 50.20 & & 14.16 \\
\hline
\end{tabular}

a As mg kg DM ${ }^{-1}$

varieties differed considerably either quantitatively or qualitatively. It can be seen that the major phenolic compounds found in Pelese apricots are the flavonols, followed by hydroxycinnamic acids and flavanols. The most common compounds for the three classes are rutin, neochlorogenic acid and catechin. Other compounds found were chlorogenic acid, epicatechin and quercetin 3-O-glucoside, while two other peaks were quantified as rutin equivalent and epicatechin equivalent. We did not found gallic, caffeic, p-coumaric and ferulic acid, as reported recently [10]. Regarding the probable presence of procyanidins, quercetin 3-galactoside and kampferol-3-rutinoside identification we preferred not to make assignments, due to the unavailability of standards. Polyphenol content in general and more in particular the hydroxycinnamic acid content were lower, with respect to data reported for other cultivars $[6,7,10]$, and this can be easily explained considering the cultivar factor. 
The Cafona cultivar had a different percentage distribution of the polyphenols. In fact the major compounds belong to hydroxycinnamic acids, followed by flavanols and flavonols. The most common compounds for the three classes are chlorogenic acid, rutin and catechin. Other compounds found were neochlorogenic acid and epicatechin. It was not possible to recognize other peaks. No anthocyanins were found. It is worth noting that Cafona had a very higher content of all polyphenols compared to the Pelese fruit. In particular, it is very high the chlorogenic acid content, while flavonoids and flavanoids amounts agree with those reported in literature [10, 30], even if Radi et al. [4] did not found neither catechin, nor epicatechin in Cafona fruits.

Figures 1, 2, 3, 4, 5, 6 show the changes in phenolic compounds after drying. It is first of all interesting to note the changes in the two hydroxycinnamic acids in Cafona cultivar (Figs. 1, 2). In fact apricots dried at $75{ }^{\circ} \mathrm{C}$ had a significantly higher chlorogenic and neochlorogenic acid content than those dried at $55^{\circ} \mathrm{C}$. The lower drying temperature must be responsible for the difference. The degradation of the hydroxycinnamic acids under our experimental conditions (high presence of air and, thus, oxygen) could have been influenced by polyphenoloxidase (PPO) enzymatic activity. A strong PPO activity in apricots has been, in fact, reported [4, 31]. During the dehydration process PPO activity remains high for longer periods when the drying temperature is around $55-60^{\circ} \mathrm{C}$, whereas shorter exposure period are needed to inactivate the enzyme at temperatures of $75-80{ }^{\circ} \mathrm{C}[31,32]$. In our case, although PPO activity was not studied, it is likely that degradation

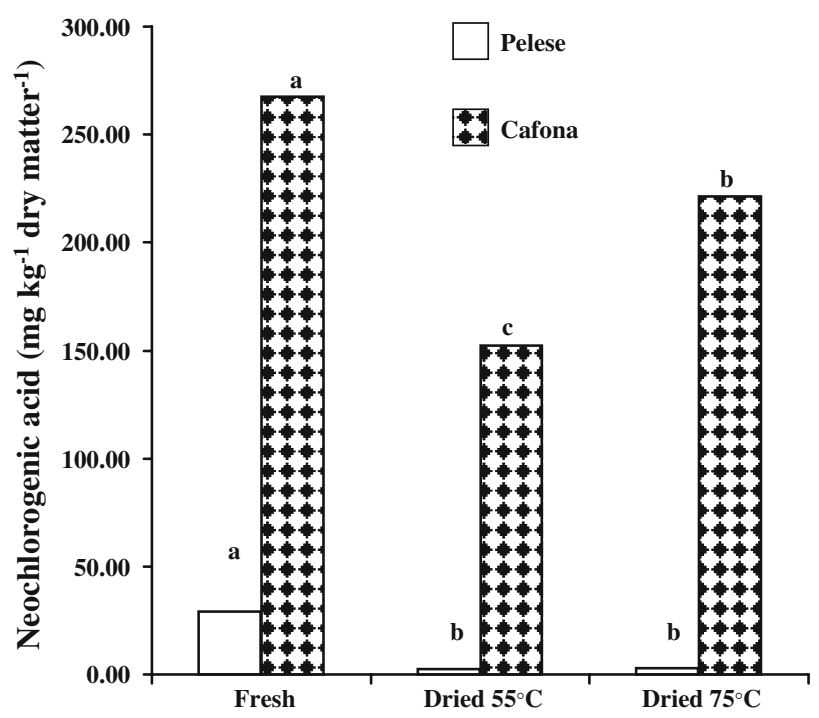

Fig. 1 Changes in neochlorogenic acid of apricots dried with two different process parameters settings. Data are the mean of three determinations. Different letters within each cultivar mean statistical difference by Duncan's multiple range test at $P \leq 0.01$

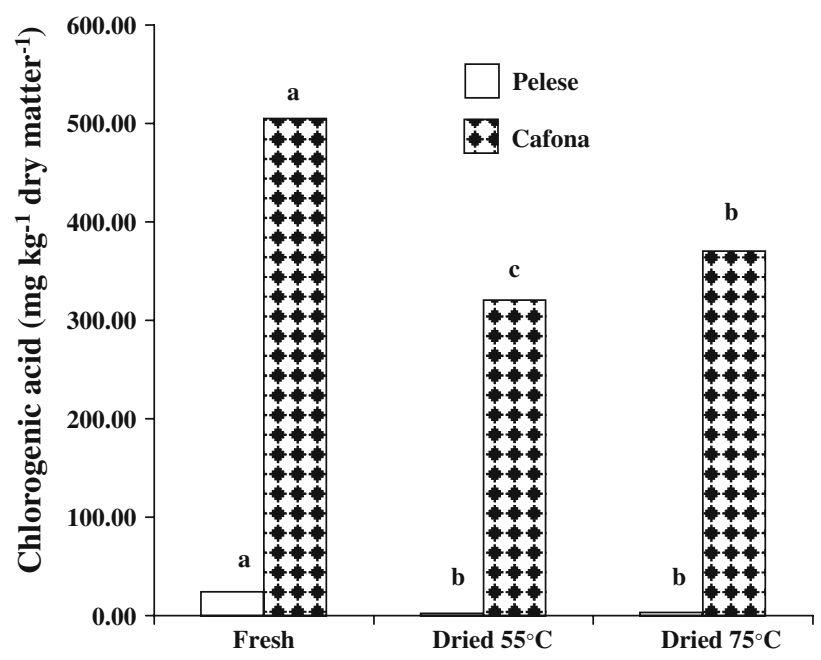

Fig. 2 Changes in chlorogenic acid of apricots dried with two different process parameters settings. Data are the mean of three determinations. Different letters within each cultivar mean statistical difference by Duncan's multiple range test at $P \leq 0.01$

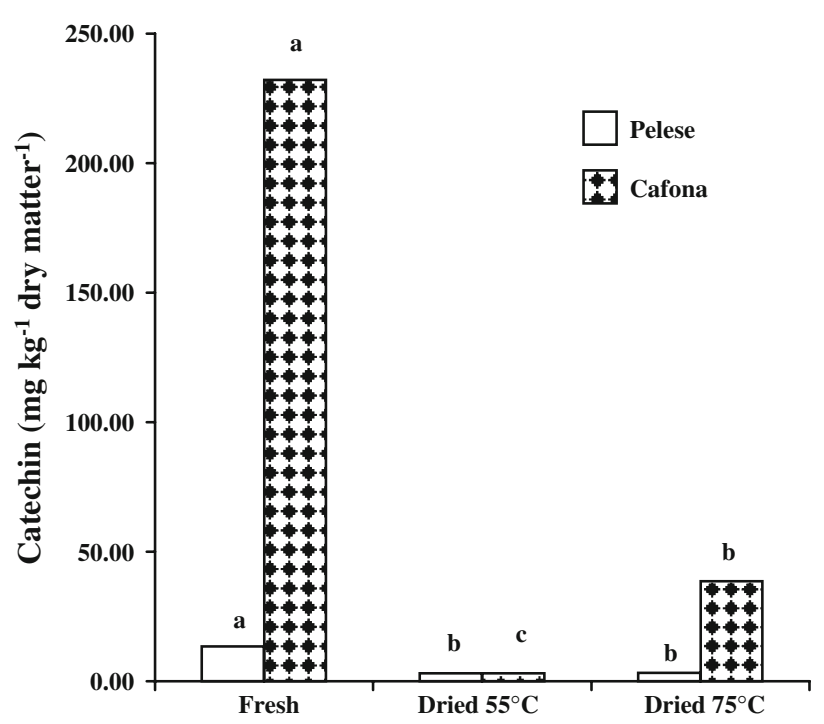

Fig. 3 Changes in catechin of apricots dried with two different process parameters settings. Data are the mean of three determinations. Different letters within each cultivar mean statistical difference by Duncan's multiple range test at $P \leq 0.01$

kinetic was the same as in the works cited. Moreover, the probable higher residual activity of PPO at the lower drying temperature went on longer, due to the higher processing time. The probable enzymatic mechanism in reducing polyphenols at a higher level in $55{ }^{\circ} \mathrm{C}$ dried fruits is confirmed by the colour evolution of apricot pulp. In fact, apricots dried at $55{ }^{\circ} \mathrm{C}$ showed a significantly higher decrease in $a^{*}$ and $L$ values than $75{ }^{\circ} \mathrm{C}$ dried fruits (data not shown). This decrease is a direct consequence of the PPO activity [4, 33, 34]. The decrease in neochlorogenic and chlorogenic acids in the Cafona apricots dried at $75{ }^{\circ} \mathrm{C}$ 


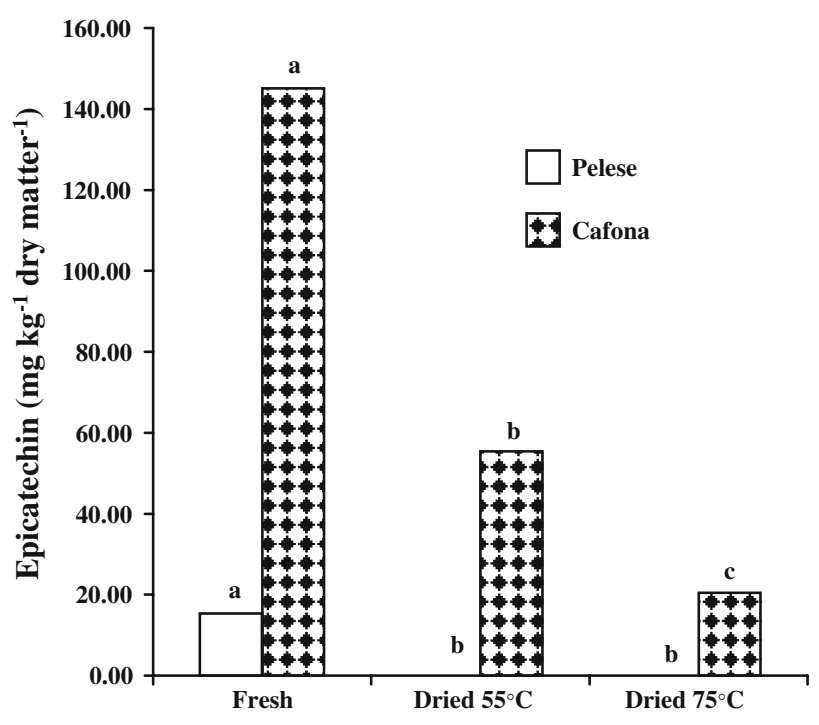

Fig. 4 Changes in epicatechin of apricots dried with two different process parameters settings. Data are the mean of three determinations. Different letters within each cultivar mean statistical difference by Duncan's multiple range test at $P \leq 0.01$

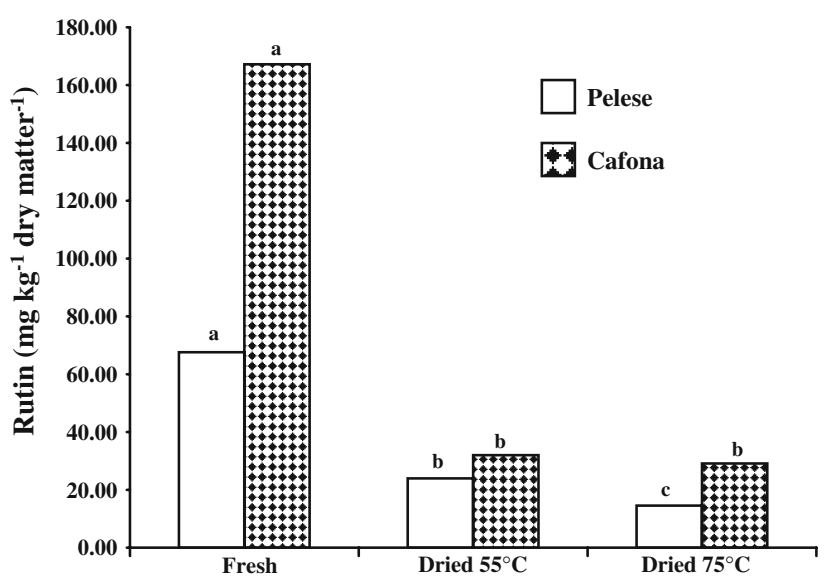

Fig. 5 Changes in rutin of apricots dried with two different process parameters settings. Data are the mean of three determinations. Different letters within each cultivar mean statistical difference by Duncan's multiple range test at $P \leq 0.01$

was of 16 and $26 \%$, respectively, in agreement with what reported by Raynal et al. [32] on plums. The Pelese fruits showed a different behaviour than Cafona apricots, as the two hydroxycinnamic acids were quite completely destroyed by processing. The very low content of these two acids can account for the lack of difference between the two drying temperatures.

Catechin showed the same behaviour of hydroxycinnamic acids in both cultivars (Fig. 3), while epicatechin loss was, in general, temperature dependent (Fig. 4), even if it has been found that epicatechin has more or less the same sensitivity to PPO than catechin $[4,35]$. The same

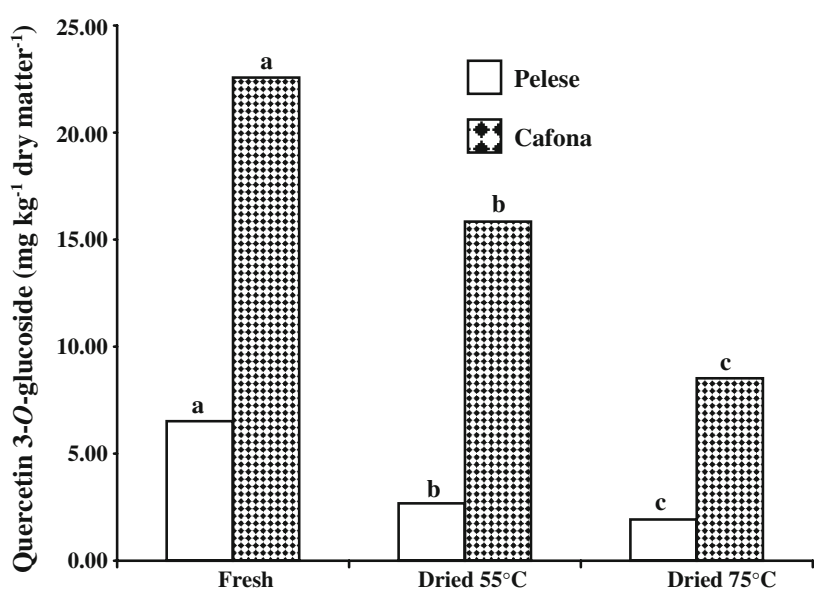

Fig. 6 Changes in quercetin $3 \mathrm{O}$-glucoside in apricots dried with two different process parameters settings. Data are the mean of three determinations. Different letters within each cultivar mean statistical difference by Duncan's multiple range test at $P \leq 0.01$

results have been obtained also for epicatechin equivalent which was found only on Pelese (data not shown).

The fate of flavonols is shown in Figs. 5, 6. The degrading action of the dehydration process is evident. In all cases, except one (Fig. 5), the decrease in flavonols was significantly more marked in the sample dried at $75^{\circ} \mathrm{C}$. It is clear, therefore, that unlike the case of hydroxycinnamic acids and catechin, the degradation of the flavonols is not directly correlated to PPO activity, since the flavonols compounds disappear proportionally to the increase in temperature. The flavonoids are therefore not degraded by the same mechanism as the phenolic acids; that is, they are not direct or poor substrates for oxidases [36, 37] since PPO does not act directly on the glycosides. The same results have been obtained also for rutin equivalent which was found only on Pelese (data not shown).

It is worth noting that all the data obtained showed the same trend and thus confirmed what previously found at our laboratories when drying plums [23].

\section{Changes in antioxidant activity and redox potential} after processing

Some authors have correlated the presence of phenolics with antioxidant activity in apricots [22, 38]. Our assays of antioxidant capacity, conducted with an electron transferbased antioxidant capacity assay, gave particularly interesting results. As can be seen in Fig. 7, the antioxidant capacity increased significantly in Cafona fruit as a consequence of increasing drying temperature, while the values did not change in the Pelese apricot. These data are confirmed by changes in redox potential values, which decreased from $382.5 \mathrm{mV}$ on fresh fruit to 340 and $319 \mathrm{mV}$ for Cafona apricot dried respectively at 55 and $75{ }^{\circ} \mathrm{C}$, 


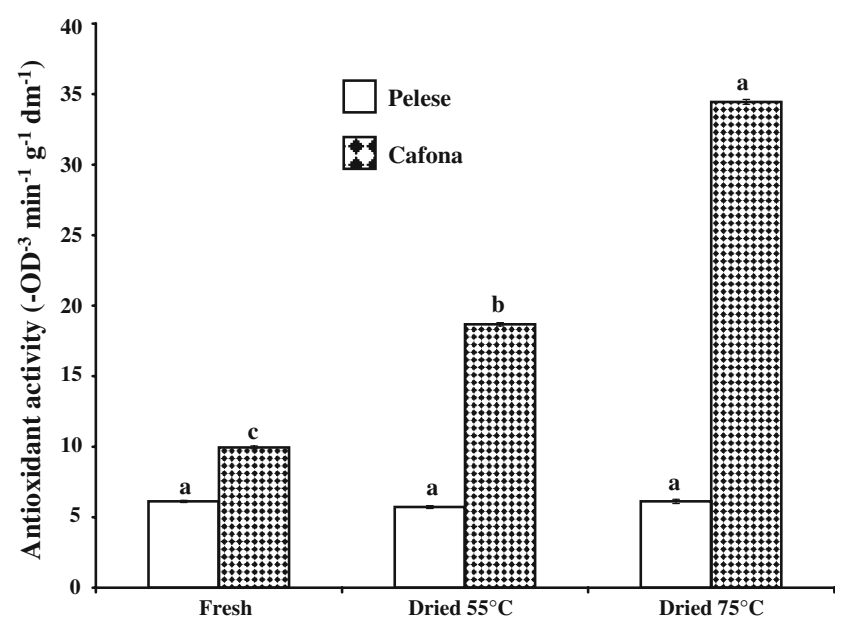

Fig. 7 Changes in antioxidant activity of apricots dried with two different process parameters settings. Data are the mean of three determinations. Different letters within each cultivar mean statistical difference by Duncan's multiple range test at $P \leq 0.01$

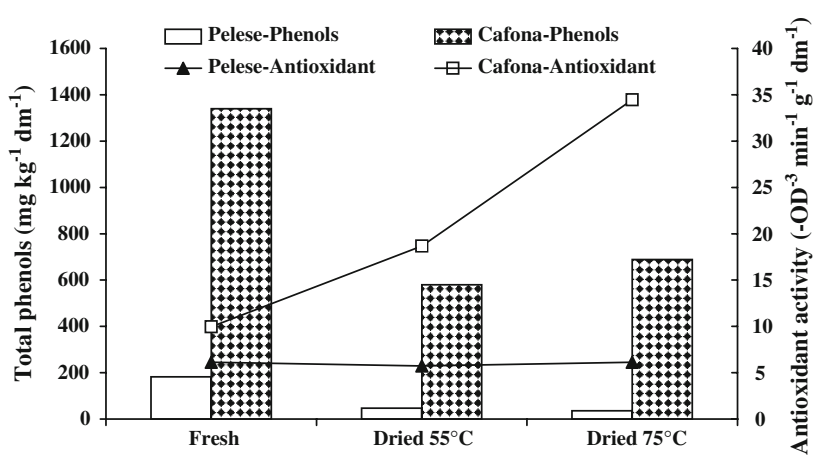

Fig. 8 Antioxidant activity and total phenols of apricots dried with two different process parameters settings. Data are the mean of three determinations

indicating an increase in the reducing properties of fruits. Redox values in Pelese apricots remained substantially unchanged (data not shown). Figure 8 shows that the sum of the polyphenols detected drastically decreased, particularly in the sample dried at the lower temperature, thus the assay should have give the opposite results, especially on Cafona apricots in which the antioxidant values were four times higher in fruits dried at $75^{\circ} \mathrm{C}$. It is to highlight that the area of the not recognised peaks decreased too, thus we have surely a decrease in the amount of polyphenols. The contemporary decrease in polyphenols and increase of antioxidant activity could be due to several factors, such as increased antioxidant power of polyphenols at an intermediate state of oxidation, increase in reducing sugar and formation of Maillard Reaction Products (MRPs), known to have a great antioxidant activity, which is often exerted in a chain-breaking and DPPH type mechanism [39-42]. These results agree with data previously reported on prunes
[23]. The Pelese cultivar, on the other hand, showed no significant changes in antioxidant activity upon drying. It could be that the probable increase in antioxidant capacity due to the above cited hypothesis served only to compensate for the decrease in antioxidant activity due to the destruction of the phenolics.

\section{Conclusion}

This study shows for the first time the changes of phenolics and antioxidant activity in apricots as influenced by hot air drying at different temperatures. The results demonstrate that phenols degradation during hot air drying did not always result in the same effects. Despite the marked reduction in phenols, which are almost in toto responsible for the antioxidant capacity, chain-breaking activity considerably increased in the Cafona dried apricots, while did not change in Pelese fruits. The higher drying temperature gave a better product from the antioxidant and polyphenol content point of view. More than one reason can explain this behaviour, thus is our intent to deeply investigate in the very next future for the causes responsible for these results.

Acknowledgments Research supported by Ministero dell'Università e della Ricerca Scientifica (MIUR) and Università degli Studi di Sassari, Programmi di Ricerca Scientifica di Rilevante Interesse Nazionale (PRIN 2005), title of the project "Studio della produzione di essiccati di albicocca ad alta qualità nutrizionale "and "Influenza di diverse condizioni di processo e della conservazione sulla capacità antiossidante delle prugne". Thanks to Dr. Murray Isman of the Department of Plant Sciences, University of British Columbia, Vancouver, for kindly supplying the standard for neochlorogenic acid.

Open Access This article is distributed under the terms of the Creative Commons Attribution Noncommercial License which permits any noncommercial use, distribution, and reproduction in any medium, provided the original author(s) and source are credited.

\section{References}

1. Kalra EK (2003) AAPS PharmSci 5(3):1-2. doi:10.1208/ ps050225

2. Macheix JJ, Fleuriet A, Billot J (1990) Fruit phenolics. CRC Press, Boca Raton

3. Garcia-Viguera C, Zafrilla P, Tomas-Barberan FA (1997) J Sci Food Agr 73:207-213. doi:10.1002/(SICI)1097-0010(199702) 73:2<207

4. Radi M, Mahrouz M, Jaouad A, Tacchini M, Aubert S, Hugues M, Amiot MJ (1997) HortScience 32:1087-1091

5. Arts CW, van de Putte B, Hollman PCH (2000) J Agr Food Chem 48:1746-1751. doi:10.1021/jf000025h

6. Dragovic-Uzelac V, Delonga K, Levaj B, Djakovic S, Pospisil J (2005) J Agr Food Chem 53:4836-4842. doi:10.1021/jf040494

7. Dragovic-Uzelac V, Pospisil J, Levaj B, Delonga K (2005) Food Chem 91:373-383. doi:10.1016/j.foodchem.2004.09.004

8. Ruiz D, Egea J, Tomas-Barberan FA, Gil MI (2005) J Agr Food Chem 53:6368-6374. doi:10.1021/jf0480703 
9. Veberic R, Stampar F (2005) Phyton-Ann Rei Bot A 45(3):375383

10. Dragovic-Uzelac V, Levaj B, Mrkic V, Bursac D, Boras M (2007) Food Chem 102:966-975. doi:/10.1016/j.foodchem. 2006.04.001

11. Fraser PD, Bramley PM (2004) Prog Lipid Res 43:228-265. doi: 10.1016/j.plipres.2003.10.002

12. Sass-Kiss A, Kiss J, Milotay P, Kerek MM, Toth-Markus M (2005) Food Res Int 38:1023-1029. doi:10.1016/j.foodres. 2005.03.014

13. Kim DO, Jeong SW, Lee CY (2003) Food Chem 81:321-326. doi:10.1016/S0308-8146(02)00423-5

14. Scalzo J, Politi A, Pellegrini N, Mezzetti B, Battino M (2005) Nutrition 21:207-213. doi:10.1016/j.nut.2004.03.025

15. Guo C, Yang J, Wei J, Li Y, Xu J, Jiang Y (2003) Nut Res 23:1719-1726. doi:10.1016/j.nutres.2003.08.005

16. Ishiwata T, Yamaguchi H, Takamura M, Matobat T (2004) Food Sci Technol Res 10:152-156. doi:10.3136/fstr.10.152

17. Crivelli G (1997) Italus Hortus 4:48-53

18. Bolin HR, Huxsoll CC, Salunnkhe DK (1981) Utiliz Res 1:19-25

19. El Halouat A, Labuza TP (1987) J Food Sci 52:342-345

20. Barbosa-Cánovas GV, Vega-Mercado H (1996) In BarbosaCánovas GV, Vega-Mercado H (eds) Dehydration of foods, Chapman \& Hall New York, pp 289-320

21. Piga A, Poiana M, Pinna I, Agabbio M, Mincione A (2004) Sciences des Aliments 24:247-259. doi:10.3166/sda.24.247-259

22. Guclu K, Altun M, Ozyurek M, Karademir SE, Apak R (2006) Int J Food Sci Technol 41(S1):76-85. doi:10.1111/j.1365-2621. 2006.01347.x

23. Piga A, Del Caro A, Corda G (2003) J Agric Food Chem 51:3675-3681. doi:10.1021/jf021207

24. AOAC (1990) Official Methods of Analysis, 15th ed, Association of Official Analytical Chemists, Arlington VA

25. Brand-Williams W, Cuvelier ME, Berset C (1995) LebensmWiss U Technol 28:25-30. doi:0023-6438/95/010025
26. Manzocco L, Anese M, Nicoli MC (1998) Lebensm-Wiss U Technol 31:694-698. doi:10.1006/fstl.1998.0491

27. Donovan JL, Meyer AS, Waterhouse AL (1998) J Agric Food Chem 46:1247-1252. doi:10.1021/jf970831x

28. Lo Voi A, Impembo M, Fasanaro G, Castaldo D (1995) J Food Com Anal 8:78-85. doi:10.1006/jfca.1995.1010

29. Ryley J, Kayda P (1993) Food Chem 49:119-129. doi: 10.1016/0308-8146(94)90148-1

30. Tsanova-Savova S, Ribarova F, Gerova M (2005) J Food Com Anal 18:691-698. doi:10.1016/j.jfca.2004.06.008

31. Arslan O, Temur A, Tozlu I (1998) J Agric Food Chem 46:1239_ 1271. doi:10.1021/jf970599v

32. Raynal J, Moutounet M, Souquet JM (1989) J Agric Food Chem 37:1046-1050. doi:10.1021/jf00088a050

33. Vamos-Vigyazo L, Nadudvari-Markos V, Gajzago I (1979) Proc Hung Annu Mtg Biochem 19:221-222

34. Vamos-Vigyazo L, Gajzago I, Nadudvari V (1981) Plant Foods Hum Nutr 31:45-60

35. Prabha TN, Patwardhan MV (1982) J BioSci 4:69-78

36. Baruah P, Swain T (1959) J Sci Food Agric 10:25-130

37. Amiot MJ, Tacchini M, Aubert S, Oleszek W (1995) J Agr Food Chem 43:1132-1137. doi:10.1021/jf00053a004

38. Tosun I, Ustun NS (2003) Pakistan J Nutr 2:167-169

39. Manzocco L, Calligaris S, Mastrocola D, Nicoli MC, Lerici CR (2001) Trends Food Sci Tech 11:340-346. doi:10.1016/S09242244(01)00014-0

40. Martins SIFS, Jongen WMF, van Boekel MAJS (2001) Trends Food Sci Tech 11:364-373. doi:10.1016/S0924-2244(01) 00022-X

41. Morales FJ, Jimenez-Perez S (2001) Food Chem 72:119-125. doi:10.1016/S0308-8146(00)00239-9

42. Morales FJ (2004) Eur Food Res Technol 218:515-520. doi:10. 1007/s00217-004-0896 